\title{
JOB INVOLVEMENT AND JOB SATISFACTION OF SOUTH AFRICAN NURSES COMPARED WITH OTHER PROFESSIONS
}

\author{
R.A. Kaplan, A.B. Boshoff, A.M. Kellerman
}

\section{UITTREKSEL}

'n Studie word besknywe waarin die vlakke van werksbetrokkenheid en werksbevrediging van Suid-Afrikaanse verpleegsters met dié van verpleegsters in die V.S.A. en Suid-Afrikaanse lede van 13 ander professies vergelyk word. Werksbetrokkenheid en werksbevrediging word gesien as aanduiding van kwaliteit van lewe, voorspellers van arbeidsomset en moontlik langlewendheid en dus as belangrike konstrukte in die werkslewe van mense.

Gestandaardiseerde instrumente, waarvan die psigometriese eienskappe ook verder ondersoek is, is in die studie gebruik Verskille tussen professies is deur middel van analise van variansie ondersoek.

Die resultate dui daarop dat Suid Afrikaanse verpleegsters se werksbetrokkenheid relatief hoog is. Hul werksbevrediging was egter uiters laag. Die implikasies van hierdie bevindinge vir die mediese professie en veral vir verpleegsters word bespreek.

\section{SUMMARY}

The study was designed primarily to compare the work outcomes of job satisfaction and job involvement of South African nurses with those of members of 13 other professional groups in South Africa and with American nurses where data was available. Secondary aims included identifying areas where job satisfaction was particularly low and demonstrating the relative independence of the job involvement and job satisfaction constructs.

A questionnaire incorporating the Kanungo Job Involvement Scale and the Short Form of the Minnesota Job Satisfaction Questionnaire was mailed to random samples of people between the ages of 29 and 41 drawn from 14 professional registers.

There were 114 nurses in the final sample and 1677 members of otherprofessions. Differences among professions were tested for significance using one-way analyses of variance and Bonferroni ranges tests.

South African Nurses were shown to have extremely low job satisfaction relative to Ameri. can nurses and to other professional groups in South-Africa. By contrast their job involvement was moderately high. The implications of these findings for the medical profession as a whole and for nurses in particular are discussed. The fear is expressed that wide spread dissatisfaction may lead to fewer people entering the profession and highly trained people leaving.

The present study attempts to provide some perspective on the response of nurses to their working environment. Two work outcomes that are powerful indicators of the quality of work life and are also predictors of staff turnover, namely job satisfaction and job involvement, were examined.

Before the research methodology and results are presented, the job satisfaction and job involvement constructs will be defined briefly. Some of the effects of satisfaction and involvement on personal and organisational life will also be outlined.

\section{JOB SATISFACTION}

The definition of job satisfaction suggested by Locke was adopted for the present study. Locke defines job satisfaction as "a pleasurable or positive emotional state resulting from the appraisal of one's job or job experiences" (Locke, 1983). Two aspects of this definition require amplification. Firstly, job satisfaction is defined as an emotion. Pleasure and displeasure are among the most basic of emotions and reflect an unconscious appraisal of the beneficial or harmful relationship of some aspects of reality upon oneself (Locke, 1969).
The second conspicuous aspect of the definition is that it offers no specific prescription of just what facets of the job or job experiences may be appraised as satisfying or dissatisfying. The truth seems to be that almost any job-related event, condition or agent (i.e. coworkers, supervisors and so on) may be evaluated positively or negatively in terms of their potentially beneficial or harmful impact. Job satisfaction then is a cumulative reaction to an extremely broed array of job facets.

Job facets may be categorized as either extrinsic or intrinsic. The extrinsic facets include such aspects of the context in which the work is performed as pay, work hours and relationships with co-workers and managers. The intrinsic facets concern the content of the work performed, whether it is interesting, varied, a source of identity and whether it exercises one's skills. Generally, the amount of autonomy one's job provides would be regarded as an intrinsic facet, but for the purposes of this study autonomy was measured separately.

The consequences of job satisfaction (or a lack thereof) have been the subject of intensive research. Returning to Locke's (1983) definition of satisfaction as an emotional response, the most obvious behavioural consequence of dissatisfaction would be avoidance, hence staff turnover or absenteeism. A great deal of empirical research has provided generally consistent support for this proposition (Locke, 1983; Mitchell, 1979; O'Reilly III \& Caldwell, 1980). Results from these studies indicate that job satisfaction may account for up to 16 percent of the variance in absenteeism and tumover.

Job satisfaction has been related to a number of variables that might be classified as quality of life variables, including general life satisfaction, physical health and longevity, and mental heal th. Mitchell (1979), Locke (1983) and Khaleque and Rahman (1987) cite $10 \mathrm{in-}$ dependent studies showing job satisfaction and life satisfaction to be correlated. Khal eque and Rahman's (1987) own study provides further evidence. Most of these studies however, are correlational and do not imply causality. Locke (1983) suggests that emotional generalization or "spillover" might 
in fact work in both directions so that work attitudes for example may affect attitudes to one's family and vice versa.

Studies relating satisfaction to physical and mental health and to longevity, have consistently yielded positive correlations (Khaleque \& Rahman, 1987; Locke, 1983). In a study by Palmore (cited in Locke, 1983) work satisfaction proved an even stronger predictor of longevity $(r=26, N=288)$ than such variables as physical exercise and tobacoo use.

\section{JOB INVOLVEMENT}

The definition and measurement of job involvement has been the subject of a great deal of controversy. A review of the literature, however, suggested that Kanungo (1982), drawing on the seminal work of Lodahl and Kejner (1965), had produced the most consistent definition and measurement. The definition of job involvement, used by Kanungo and adopted for the present study, was "a psychological identification with one's work".

Numerous possible antecedents and/or determinants of job involvement have been examined, but the construct remains largely unexplained. Job involvement seems to be determined by individuals' characteristics (that is that some people have a predisposition to be more involved in their jobs whatever the circumstances) (Lorence \& Mortimer, 1985; Mannhein \& Dubin, 1986; Moch, 1980; Morrow, 1983; Rabinowitz \& Hall, 1977). Situational variables shown to be related to job involvement include challenging work (Hall, Goodale, Rabinowitz \& Morgan, 1978), a confident and trusting leader, participation in decision making, social contact and job satisfaction (Rabinowitz \& Hall, 1977), freedom of choice in career decisions (O'Reilly III \& Caldwell, 1980), autonomy (Lorence \& Mortimer, 1985) and pressure for quality work (Lawler \& Hall, 1970). Furthermore an interaction between individual differences and situational characteristics has been shown to influence job involvement (Kanungo, 1982).

Rabinowiz and Hall (1977) suggest that job involvement is a "feedback variable", simultaneously a cause and an effect of job behaviour. Research into job involvement as a cause has focused primarily on job performance, employee turnover and absenteeism as dependent variables.

Numerous studies investigating a possible relationship between job involvement and performance have produced disappointing results. However, the work of Vroom (1962), Hall and Lawler (1970) and Rabinowiz (1985) does indicate at least a weak correlation between job involvement and job performance. Possibly the relationship is unclear becauce performance goals may not be clear within the control and ability of employee, or short-term enough to show a direct correlation between involvement and performance.
In line with intuitive thinking, high job involvement has been associated with low staff turnover and low absenteeism. There are discrepancies in the degree of prediction various studies achieve, ranging from as much as $\mathbf{1 6}$ percent of the variance in staff turnover to as little as two percent (Blau \& Boal, 1987). Job involvement seems to predict turnover more consistently than absenteeism and the frequence of absences rather than the duration (Farris, 1971; Seigel \& Ruh, 1973).

The present study was designed to survey and compare the satisfaction and involvement experienced by nurses with that of members of other professions. In an attempt to isolate more specific areas of concern, comparisons were also made across three components of job satisfaction, i.e. extrinsic satisfaction, intrinsic satisfaction and a measure of satisfaction worth the amount of autonomy the job allows dubbed autonomic satisfaction. Furthermore, the general job satisfaction of nurses was compared to American norms for that profession.

\section{METHOD}

For a detailed description of the research methodology employed in this survey, readers are referred to Boshoff, Kaplan, Schutte and Kellerman (1989). Only a brief synopsis of the methodology will be presented here

\section{SAMPLE}

Random samples of approximately 300 people between the ages of 29 and 41 years were drawn from the professional registers of each of 14 professions (see Table I). Each subject was sent a questionnaire and a postage paid return-envelope in either English or Afrikaans if a preference could be determined from the register. Follow up letters and an offer of personal feedback on the results of the survey were used in an attempt to ensure a good return rate. In the event, out of 4084 questionnaires mailed initially, 1791 usuable questionnaires were retumed - a response rate close on $44 \%$. A break down of samples by profession, age, sex and language is given in Table I.

\section{MEASURING INSTRUMENTS}

English and Afrikaans versions of the measuring instruments were prepared using a translation-retranslation procedure to ensure consistency. They were also subjected to a rigorous psychometric validation before being used in further analyses. The translation and validation procedures are described in detail in Boshoff, Kaplan, Schutte and Kellerman (1989).

Job satisfaction was measured using the Short Form of the Minnesota Satisfaction Questionnaire (1967). The instrument consists of 20 items measuring satisfaction with job facets such as ability utilization, advancement, compensation and responsibility.

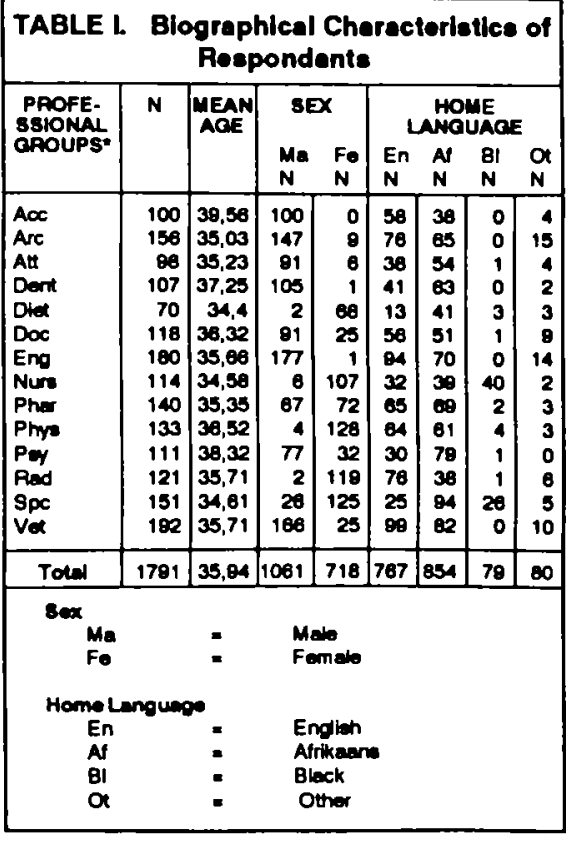

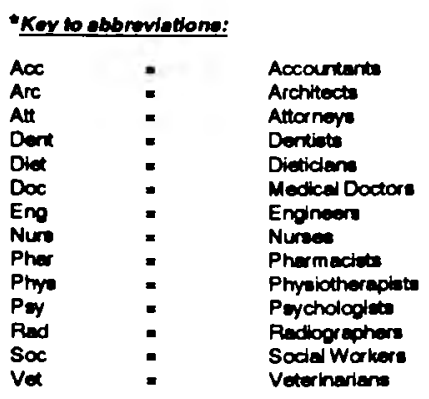

Job involvement was measured using nine items of the Kanungo Job Involvement Scale (Kanungo, 1982). The scale is exemplified by items such as :

- Most of my personal life goals are job oriented.

- I consider my job to be very central to my existence.

The psychometric evaluation consisted of factor analyses (both Principal Components, Analysis and Principal Factor Analysis with Varimax rotation) to determine the underlying dimensions measured by the two instruments. The results indicated that job involvement and job satisfaction were factorially distinct. It further indicated that nine out of ten items in the Job Involvement Questionnaire developed by Kanungo loaded undimensionally on the Job Involvement dimension. The items in the Minnesota Satisfaction Questionnaire appeared to have three underlying dimensions (factors) i.e. Extrinsic, Intrinsic and Autonomous Job satisfaction. These scales correlated significantly with each other. Intemal reliability coefficients of the obtained factor scales are shown in Table II. Statistical analyses as part of the study reported here were based on the scores on the factor scales derived from the factor analyses described above.

Overall differences between the professional groups on each of the variables under study were tested for significance using one-way 


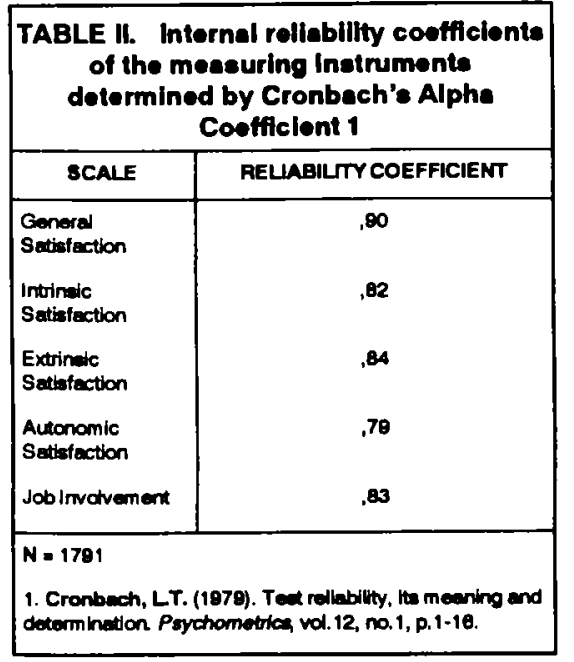

analyses of variance, and significant differences were further isolated using the Bonferroni Ranges Test.

\section{RESULTS}

The mean of general satisfaction scores for the sample of South African nurses was compared with normative data for American comparison groups (Nunnally, 1978). The results of the comparisons are reflected in Table III.

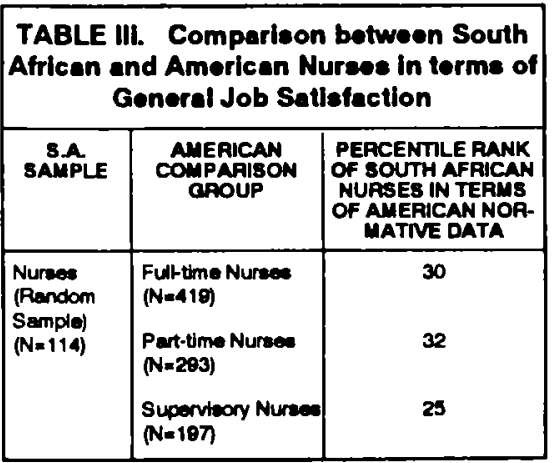

These results indicate that $70 \%$ of full-time, $68 \%$ of part-time and $75 \%$ of supervisory nurses in the USA, on whom the instrument was standardized, have higher job satisfaction than the average South African nurse. South African nurses therefore experience substantially less job satisfaction than their American counterparts.

The results of the one-way analyses of variance are summarized in Tables IV through VIII.

The resul ts reflected in Table IV show nurses to have the numerically lowest overall satisfaction of all the professions sampled and to have significantly lower overall satisfaction than 10 out of 13 professional groups.

Similarly on the factors included in the overall satisfaction measure - extrinsic satisfaction, intrinsic satisfaction and autonomic satisfaction - nurses scored particularly low as reflected in Tables V, VI and VIII respectively.

Nurses had the lowest scores numerically on the autonomic and extrinsic job satisfaction factors. They also returned extremely low scores on the intrinsic job satisfaction scale.

\begin{tabular}{|c|c|c|c|}
\hline \multicolumn{4}{|c|}{$\begin{array}{l}\text { TABLE IV. Summery } \\
\text { Analyale of Veriance } \\
\text { renges test for Dopen } \\
\text { Overall Job Sat } \\
\text { Overal diference among oroups: } \\
\text { E }(13 ; 1776)=10,25, \mathrm{Q}<, 0001\end{array}$} \\
\hline $\begin{array}{l}\text { PROFE- } \\
\text { SSION }\end{array}$ & MEAN & $\begin{array}{l}\text { PROFESSIONS } \\
\text { WTH } \\
\text { SIGNIFICANTLY } \\
\text { LESS JOB } \\
\text { SATISFACTION }\end{array}$ & $\begin{array}{l}\text { PROFESSIONS } \\
\text { WITH } \\
\text { SIGNIFICANTLY } \\
\text { GREATER JOB } \\
\text { BATISFACTION }\end{array}$ \\
\hline$A C C$ & 62,68 & $\begin{array}{l}\text { Red, Eng Doc, } \\
\text { Veg } \\
\text { Dlet, Soc, Pher, } \\
\text { Nure }\end{array}$ & \\
\hline Phys & 81,24 & $\begin{array}{l}\text { Arc, Rad, Eng, } \\
\text { Doc, Vot, Diot, } \\
\text { Soc, } \\
\text { Phe, Nure }\end{array}$ & \\
\hline$P=y$ & 79,27 & $\begin{array}{l}\text { Eng Vot, Soc, } \\
\text { Phar, Nure }\end{array}$ & \\
\hline Dent & 77,73 & So, Phar, Nurn & \\
\hline Arc & 77,70 & Nure & Phys \\
\hline Rad & 76,88 & Nurs & Acc, Phys \\
\hline Eng & 76,34 & Nurs & Acc, Phys, Att \\
\hline Doc & 76,00 & Nurs & Acc, Physe \\
\hline Vet & 76,06 & Nure & Acc, Phye, Att \\
\hline Diet & 75,70 & Murs & Acc, Phyre \\
\hline Sœ & 74,41 & & $\begin{array}{l}\text { Acc, Phyt, Att, } \\
\text { Pey }\end{array}$ \\
\hline Pher & 73,80 & & $\begin{array}{l}\text { Aoc, Phya, Alt, } \\
\text { Pwy }\end{array}$ \\
\hline Nurs & 70,87 & & $\begin{array}{l}\text { Acc, Phya, Ath, } \\
\text { Poy, Dent, Arc, } \\
\text { Rad, Eno. Doc, } \\
\text { Vot }\end{array}$ \\
\hline
\end{tabular}

TABLE V. Summary of the One-way Anelyale of Varlance and Bonferroni ranges teet for Dependent Veriable Extrinaic Job Satlafaction

Overell difference among group: $F(13 ; 1776)=11,17, E<, 0001$

\begin{tabular}{|c|c|c|c|}
\hline $\begin{array}{l}\text { PROFE- } \\
\text { SSION }\end{array}$ & MEAN & $\begin{array}{c}\text { PROFESSIONS } \\
\text { WIMH } \\
\text { SIGNIFICANTLY } \\
\text { LESS } \\
\text { EXTRINBIC JOB } \\
\text { SATISFACTOON }\end{array}$ & $\begin{array}{l}\text { PROFESSIONS } \\
\text { WTTH } \\
\text { SIONIFICANTLY } \\
\text { OAEATER } \\
\text { EXTRINSIC JOB } \\
\text { SATISFACTION }\end{array}$ \\
\hline$A c c$ & 31,31 & $\begin{array}{l}\text { Pey, Eno, Vet, } \\
\text { Dent, Pher, Red, } \\
\text { Did, Doc, Soc, } \\
\text { Nure }\end{array}$ & \\
\hline Phye & 30,51 & $\begin{array}{l}\text { Eng, Vot, Dent, } \\
\text { Pher, Red, Disc, } \\
\text { Doc, Soc, Nure }\end{array}$ & \\
\hline Att & 29,89 & $\begin{array}{l}\text { Pher, Red, Doc, } \\
\text { Soc, Nure }\end{array}$ & \\
\hline Are & 28,02 & $80 c$, Nure & \\
\hline Poy & 26,21 & Nurs & $A \infty C$ \\
\hline Eng & 28,03 & Nurs & $A x$, Phys \\
\hline Vet & 27,03 & Nure & Acc, Phys \\
\hline Dent & 27,47 & & Acc, Phye \\
\hline Phar & 27,20 & & Acc, Phya, Att \\
\hline Red & 27,11 & & Acc, Phya, Al \\
\hline Diet & 27,00 & & Acc, Phye \\
\hline$D \propto c$ & 26,62 & & Acc, Phys Att \\
\hline$S \propto$ & 28,23 & & $\begin{array}{l}\text { Acc, Phyar, Att, } \\
\text { Are }\end{array}$ \\
\hline Nure & 24,85 & & $\begin{array}{l}\text { Acc, Phys, Alt, } \\
\text { Arc, Poy, Eng. } \\
\text { Vet }\end{array}$ \\
\hline
\end{tabular}

TABLE VL. Summery of the One-way Analyale of Veriance and Bonferron renges teat for Dopendent Varlable Intrinaic Job Satiafaction

Overall difference em ong group $E(13 ; 1776)-0,51, P<.0001$

\begin{tabular}{|c|c|c|c|}
\hline $\begin{array}{l}\text { PAOFE- } \\
\text { SSION }\end{array}$ & MEAN & $\begin{array}{l}\text { PROFESBIONS } \\
\text { WTHH } \\
\text { SIONIFICANTLY } \\
\text { LFSS } \\
\text { INTRINSIC JOB } \\
\text { SATSFACTON }\end{array}$ & $\begin{array}{l}\text { PAOFESSIONS } \\
\text { WTH } \\
\text { SIGNIFICANTLY } \\
\text { GAEATEER } \\
\text { INTPINBIC JOB } \\
\text { SATSFACTION }\end{array}$ \\
\hline Prys & 38,82 & $\begin{array}{l}\text { 8oc, Arc, Dent, } \\
\text { Eng. Vet, Nurs, } \\
\text { Pher }\end{array}$ & \\
\hline$A \propto c$ & 38,08 & Vat Nura, Pher & \\
\hline Py & $\mathbf{3 7 , 9 7}$ & Vet, Nure, Phar & \\
\hline Att & 37,80 & Pher & \\
\hline Fled & 37,50 & Pher & \\
\hline Doc & 37,13 & & \\
\hline Dent & 37,12 & & \\
\hline $8 \propto c$ & 36,20 & & Phye \\
\hline Ave & 36,07 & & Phye \\
\hline Diet & 36,00 & & Phye \\
\hline Eno & 35,60 & & Phys \\
\hline Vor & 35,77 & & Phys, Acc, Poy \\
\hline Nure & 35,50 & & Phy, Acc, Poy \\
\hline Pher & 34,82 & & $\begin{array}{l}\text { Physe, Aca, Poy, } \\
\text { Att, Red }\end{array}$ \\
\hline
\end{tabular}

Given the effect of the "emotional spillover" discussed earlier, it is possible that any intrinsic satisfaction in the job is depressed by the extremely low level of extrinsic and autonomic satisfaction.

Of particular concem is the fact that nurses score significantly lower, statistically, than any other profession on the autonomic satisfaction measure, as reflected in Table VII (over page)

In contrast to their low satisfaction, nurses have moderately high job involvement (See Table VIIl over page). It is possible that high involvement in a job exacerbates the effect of working conditions on job satisfaction. It may be postulated that where one is more involved in a job, relatively small changes in oocupational conditions may have a more pervasive influence resulting in the experience of extremes of satisfaction or dissatisfaction. This may be the case with nurses in South Africa at present.

\section{CONCLUSIONS}

The findings reported in this paper may be summarized as follows: In the case of general job satisfaction the sample of South African nurses scored substantially lower than their American counterparts. Furthermore, in comparison with samples of 13 other South African professional groups, South African nurses had the lowest average numerically and scored statistically lower than 10 of the groups at the $95 \%$ confidence level. Results for each of the satisfaction subscales were similarly disturbing - with the findings with regard to Autonomic and Extrinsic factors par- 


\begin{tabular}{|c|c|c|c|}
\hline \multicolumn{4}{|c|}{$\begin{array}{l}\text { TABLE VII. Summary } \\
\text { Analyals of Veriance } \\
\text { ranges test for Depen } \\
\text { Autonomic Job Se } \\
\text { Overall difterence anong groups: } \\
E(13 ; 1778)=14,00, \mathrm{Q}<, 0001\end{array}$} \\
\hline $\begin{array}{l}\text { PAOFE- } \\
\text { SSION }\end{array}$ & MEAN & \begin{tabular}{|c|} 
PROFESSIONS \\
WTH \\
SIGNIFICANTLY \\
LESS \\
AUTONOWIC JOB \\
SATSFACTON
\end{tabular} & $\begin{array}{l}\text { PROFESSIONS } \\
\text { WTHH } \\
\text { SIONIFICANTLY } \\
\text { OREATTER } \\
\text { AUTONOWIC JOB } \\
\text { SATISFACTION }\end{array}$ \\
\hline Att & 13,35 & $\begin{array}{l}\text { Red, Soc, Phor, } \\
\text { Nure }\end{array}$ & \\
\hline$A \propto C$ & 13,28 & Soc, Pher, Nurs & \\
\hline Phys & 13,17 & Soc, Pher, Nure & \\
\hline Dent & 13.14 & Soc, Pher, Nure & \\
\hline Poy & 13,00 & Soc, Pherr, Nure & \\
\hline Arc & 12,71 & Nure & \\
\hline Diet & 12,70 & Nurs & \\
\hline Vat & 12,68 & Nurs & \\
\hline Ene & 12,42 & Nurs & \\
\hline$D \propto c$ & 12,32 & Num & \\
\hline Read & 12,28 & Nurs & Att \\
\hline Soc & 11,88 & Nurs & $\begin{array}{l}\text { Att, Acc, Ptys } \\
\text { Dent, Phys }\end{array}$ \\
\hline Pher & 11,88 & Nurn & $\begin{array}{l}\text { Au, Acc, Phys, } \\
\text { Dent, Poy }\end{array}$ \\
\hline Nurs & 10,42 & & $\begin{array}{l}\text { Att, Acc, Phys, } \\
\text { Dort, Poy, Arc, } \\
\text { Dite, Vot, Eng, } \\
\text { Doc, Reo, Soc, } \\
\text { Pher }\end{array}$ \\
\hline
\end{tabular}

TABLE VIII. Summery of the One-way Analysis of Verlance and Bonferronl ranges tost for Dopendant Variable Job Involvement

Overall difference among group: $E(13 ; 1777)=10.79, \mathrm{P}<, 0001$

\begin{tabular}{|c|c|c|c|}
\hline $\begin{array}{l}\text { PROFE- } \\
\text { SSION }\end{array}$ & MEAN & $\begin{array}{l}\text { PROFESSIONS } \\
\text { WITH } \\
\text { SIGNIFICANTLY } \\
\text { LOWER JOB } \\
\text { NVOLVEMENT }\end{array}$ & $\begin{array}{l}\text { PROFESSIONS } \\
\text { WITH } \\
\text { SIONIFICANTLY } \\
\text { GREATER DOB } \\
\text { INVOLVEMENT }\end{array}$ \\
\hline Arc & 57,77 & $\begin{array}{l}\text { Eng, Dert, Soc, } \\
\text { Phe, Phys, Diet, } \\
\text { Pad }\end{array}$ & \\
\hline$A \infty$ & 56,80 & $\begin{array}{l}\text { Soc, Pher, Phys, } \\
\text { Dle, Reod }\end{array}$ & \\
\hline Ant & 55,68 & $\begin{array}{l}\text { Soc, Pher, Phys, } \\
\text { Die, Red }\end{array}$ & \\
\hline Vet & 55,25 & $\begin{array}{l}\text { Soc, Phor, Phye, } \\
\text { Die, Rod }\end{array}$ & \\
\hline Nurs & 53,57 & Phys, Diat, Rad & \\
\hline$D \propto C$ & 53,06 & Phye, Red & \\
\hline 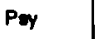 & 51,71 & Red & Are \\
\hline Eng & 51,22 & Rad & Arc \\
\hline Dent & 50,28 & Read & Arc, Acc, Att, Vet \\
\hline$S \propto C$ & 48.43 & & Arc, Acc, Ate, Vex \\
\hline Pher & 48,39 & & Are, Ace, Ath, Vot \\
\hline Phys & 46,08 & & Nurs, Do \\
\hline Diet & 45,73 & & $\begin{array}{l}\text { Aoc, Avc, Att, Vot, } \\
\text { Nurs }\end{array}$ \\
\hline Red & 43,55 & & $\begin{array}{l}\text { Ave, Acc, Aut, Vot, } \\
\text { Nurn, Doc, Poy. } \\
\text { Eng }\end{array}$ \\
\hline
\end{tabular}

ticularly noteworthy. It is clear that the primary causes of nurses' dissatisfaction stem from factors extrinsic to the work itself, for example pay, work hours and job autonomy.
As far as job involvement was concerned, nurses scored moderately high in comparison to other South African professional groups. It is likely that they would be even more involved if they were more satisfied.

The implications of these findings are alarming for nurses themselves and for the medical profession as a whole. If the present low level of satisfaction is prolonged, there is evidence that it may prove physically and mentally debilitating for the nurses themselves, particularly in light of their relatively intense involvement in their work (Locke, 1983; Khaleque \& Rahman, 1987). While the low job satisfaction is unlikely to have a marked effect on the job performance of nurses (Locke, 1983), it is likely to be felt in terms of increasing numbers leaving the profession, given the clear correlation between dissatisfaction and staff turnover (Locke, 1983; Mitchell, 1979; O'Reilly III \& Caldwell, 1980). It is also probable that such widespread dissatisfaction will result in fewer entrants to the profession and consequent shortages of nurses would have direct implications for the quality of medical care that can be offered in the longer term. If the scenario that has been sketched is to be avoided, specific causal agents, circumstances and events at the root of nurses' dissatisfaction need to be identified and re-dressed as a matter of urgency.

\section{REFERENCES}

BLAU, G.J. AND BOAL, K.B. (1987). Conceptualizing how job involvement and organizational commitment affect turnover and absenteeism. Academy of Management Review, vol.12, no.2, 228-300

BOSHOFF, A.B., KAPLAN, R.A.L., SCHUTTE, J.L. and KELLERMAN, A.M (1989). Job satisfaction, job involvement and career anchors of professionals in a Third world/First world country. Proceedings of the Second International Conference on Comparative Management. Kaohsiung: Taiwan, 80-112

FARRIS, G.F. (1971). A predictive study of turnover. Personnel Psychology, vol.24, 311-328.

HALL, D.T., GOODALE, J.G., RABINOWITZ, S. and MORGAN, M.A. (1978) Effects of top-down department and job change upon perceived employee behaviour and attitudes: A natural field experiment. Journal of Applied Psychology, vol.63, no.1, 62-72.

HALL, D.T. and LAWLER, E.E. (1970). Job characteristics and pressures and the organizational integration of professionals. Administrative Science Quarterly, vol.15, 271-281.

KANUNGO, R.N. (1982). Measurement of job and work involvement. Journal of Applied Psychology, vol.67, no.3, 341-349.
KHALEQUE, A. and RAHMAN, M.A (1987). Perceived importance of job facets and overall job satisfaction of industrial workers. Human Relations, vol.40. no.7, 401-416.

LAWLER, E.E. and HALL, D.T. (1970). Relationship of job characteristics to job involvement, satisfaction, and intrinsic motivation. Journal of Applied Psychology, vol.54, no.4, 305-312.

LOCKE, E.A. (1969). What is job satisfaction? Organizational Behavior, vol.4, 309-336.

LOCKE, E.A. (1983). The nature and causes of job satisfaction. In M.D. Dunnette, (Ed.), Handbook of Industrial and Organizational Psychology (1297-1349). New York: McGraw-Hill.

LODAHL, T.M. and KEJNER, M. (1965). The definition and measurement of job involvement. Journal of Applied Psychology, vol. 49, no.1, 24-33.

LORENCE, J. and MORTIMER, J.T. (1985). Job involvement through the life course: $A$ panel study of three age groups. American Sociological Review, vol.50, 618-638.

MANNHEIM, B. and DUBIN, R. (1986). Work role centrality of industrial workers as related to organizational conditions, task autonomy, managerial orientations and personal characteristics. Journal of Occupational Behavior, vol.7, 107-124

MITCHELL, T.R. (1979). Organizational behavior. Annual Review of Psychology vol.30, 243-281.

MOCH, M.K. (1980). Job involvement, internal motivation, and employees integration into networks of work relationships. Organizational Behavior, vol.25, 15-31.

MORROW, P.C. (1983). Concept redundancy in organizational research: The case of work commitment. Academy of Management Review, vol. 8, no. 3, 486-500.

NUNNALLY, J. (1978). Psychometric theory. New York: McGraw-Hill.

O'REILLY III, C.A. and CALDWELL, D.F (1980). Job choice: The impact of intrinsic and extrinsic factors on subsequent satisfaction and commitment. Journal of Applied Psychology, vol.65, no.5, 559-565.

RABINOWITZ S. (1985). Academic job involvement and performance: Another look. Psychological Reports, vol.57, 1007-1012.

RABINOWITZ, S. and HALL, D.T. (1977). Organizational research on job involvement. Psychological Bulletin, vol.84, no.2, 265-288.

SEIGEL, A.L. and RUH, R.A. (1973). Job involvement, participation in decision making, personal background and job 
behavior. Organizational Behavior, vol.9, 318-327.

VROOM, V.H. (1962). Ego-involvement, job satisfaction and job performance. Personnel Psychology, vol.15, 159-177.
WEISS, D.J. DAWIS, R.V., ENGLAND, G.W. and LOFQUIST, L.H. (1967). Manual for the Minnesota Satisfaction Questionnaire. Minneapolis: University of Minnesota.
A B Boshoff

Graduate School of Management University of Pretoria

RA Kaplan

Grachuate School of Management University of Pretoria

A Kellerman

Department of Psychology

University of Cape Town 